\title{
On-Line English Learning in The Perception of Twelfth Grade Students at SMA Negeri 3 Palu
}

\author{
Fikar Febrian $^{1 *}$, Hasan Basri $^{2}$, Sriati Usman ${ }^{3}$, Anshari Syafar ${ }^{4}$, Aminah Suriaman $^{5}$ \\ ${ }^{1}$ Student at English Education Study Program, Postgraduate School, Faculty of Teacher Training and Education, Tadulako \\ University \\ ${ }^{2,3,4,5}$ Lecturer at English Education Study Program, Postgraduate School, Faculty of Teacher Training and Education, Tadulako \\ University
}

\begin{abstract}
The study discusses students' perception over on-line English Learning from the twelfth grade students at SMA Negeri 3 Palu. This study uses qualitative research approach with online survey method through Kobbo Collect for collecting the data. 86 twelfth grade students were chosen as the sample from 431 population by using the convenience sampling technique. Two English teachers were involved in this study as secondary data.The data was collected using a 25 items close-ended questionnaire and 25 questions open-ended statement for teachers interview question items divided into 6 variables, The general perception on on-line learning, Students' achievement, Teachers' Competence, Learning Media and Tools, Parental Support and Financial. The findings of the study were suggested that on-line English learning based on students' perception generally still considered far from expected. On-line learning causes a decrease on students' English grades. The burdensome of homework and project from the English teacher in on-line English learning do not accompanied with good material and media that used by the English teacher. The teacher implies their bad performance due to the fact that there was no training session regarding on-line learning before. The lack of proper electronic devices and powerless internet from the network provider also had both teacher and students. Parents were still lack of understanding regarding the on-line learning process that cause interference during the learning session. Although on-line learning using digital media but somehow, students still have to pay for English books, including a way to provide a good internet connection to successfully conducting on-line learning.
\end{abstract}

Keywords: Perception, On-line Learning, English Subject

\section{INTRODUCTION}

$\mathrm{W}$ FH stands for work from home which means every work is done at home, not in the office. The WFH policy is contained in the Executive Ministry Letter of the Minister for Administrative Reformand Bureaucratic Reform (PAN \& RB) Number 50/2020 concerning the Second Amendment to the Executive Ministry Letter of the Minister of PAN \& RB Number 19/2020 concerning Adjustment of Apparatus Work Systems State Civilians in Efforts to Prevent the Spread of Covid-19 in Institutions Government. To keep the teaching and learning activities at schools running, teachers as government employees are expected to do their jobs through on-line media. These on-line media involve not only the teachers but also students. Teachers and students are required to work at home with on-line learning as the offering solution.

Learning policy that contained on-line learning regulations for students is not ended on learning on-line learning only because social distancing/restrictions is also applied with the Executive Ministry Letter that issued by Minister of Education and Culture Republic of Indonesia issued in the Executive Ministry Letter Number 4 of 2020 Concerning Implementation of Internal Education Policy Coronavirus Spread Emergency Period Disease (Covid-19) point 2 is process learning from home is implemented with the following conditions:

a. Learn from home through on-line / distance learning is implemented to give meaningful learning experiences for students, without being burdened with the demands of completing the curriculum requirements for grade promotion and graduation;

b. Learning from home can be focused on life skills education among others, regarding the pandemic COVID-19;

c. Learning activities and tasks study from home can vary among students, according to interests and conditions each, including consideration of access gaps and learning facilities at home;

d. Evidence or product of learning activities from home that are used as a tool by the teacher is qualitative report, without being obliged to give quantitative scores / grades.

The Integration of resource in terms of facility which used in traditional (off-line) and E-learning is a democratic decision for bridge the swift of currents on-line learning resources and difficulty escaping from exploitation learning resources used in the classroom (off-line). That is, the sophisticated on-line learning on technology is used is not to replace the implementation of face-to-face learning because the face-to-face interaction conventional method is still much more effective compared to on-line learning. In addition, the limitations of internet accessibility, hardware (hardware) and software (software), and financing is often an enemy in maximizing resources on-line learning. 
English subject is the subject that obligated to be taught in high school level that strongly contained in K13. English subject in the current curriculum requires continuous practice by the students. As mentioned by Imansyah (2019), one of the main problems affecting students' achievement in learning English is teacher's performance. Teacher's performance in the classroom is the main factor that affecting students in mastering English especially in speaking skills moreover in the aspect of students' speaking confidence. This statement indicates how teaching English subject even the conventional face-to-face communication still difficult to do.

Furthermore, the implementation of the process online learning in English subject has several obstacles. One of the most challenging obstacles in on-line learning for teaching English subjects is that there are still many students who think English is a difficult subject that requires a direct mentor and model from the teacher. The difficulties that exist in English require the creativity of English teacher to develop learning, both in terms of methods and the media used.

Furthermore, that policy issued indeed cannot make sure everything works out as it should be in all levels, especially schools that have never specifically applied this type of teaching and learning activity. The availability of integrated technology to support the on-line learning process is highly expected. And limited funds and inadequate facilities faced by teachers and students make the results of on-line learning not as effective as expected.

The statement above and some specific reasons that cause the researcher to conduct this research in SMA Negeri 3 Palu is due to the fact that the school have never applied online learning before and have a high chance on facing many difficulties including the problem above that effecting the effectiveness of on-line learning. This assumption based on a short interview with the English teacher and some students of the school that stated "Since it is the first time on-line learning is challenging and helpful at the same in this pandemic situation". By that reason researcher is interested in conducting this research while this research aims to get information regarding the on-line english learning on the perception of the twelfth grader at SMA Negeri 3 Palu.

\section{METHODOLOGY}

\section{Design of the research}

This research used a survey method with descriptive analysis. The actual survey research method is a form of activity that has become a habit in the scientific community. Survey research developed as a form of the positivist approach to the social sciences. Survey research asked several respondents about their beliefs, opinions, characteristics, and behaviors that have occurred or are currently occurring. The survey method provide sresearch questions about belief reports or self behavior. The questions become sharper when responding provide answers to a question with variables desired. The survey provides questions for research on the report self-belief / belief or behavior. The questions became sharper when respondents provide answers to questions with the desired variables (Groves, 2010).

\section{Subject of the Research}

In this research, the subject was all the students in the twelfth grade at SMA Negeri 3 Palu. It has consisted of 14 classes that have a different number of students in each class and two English teachers that teach English subject for all the classes. The sample of this study was taken by using the convenience sampling technique. A convenience sampling is a sampling procedure to select a sample of people or units that are the most easily encountered or accessed (Creswell, 2012). The researcher used the convenience sampling technique because it allows the researcher to conveniently exploring the subject or social situation under the study. It also allows the researcher to chose 86 students from the 14 classes whom were easily accessible to be the respondent of this research in pandemic situation. Arikunto (2006) states that sample of a research is at least $10-15 \%, 20-50 \%$ or $100 \%$ of the total population. Therefore, the researcher chose conveniently $20 \%$ students to be the sample or equal to 86 becoming respondents for this research from 431 students.

\section{Technique of Data Collection}

Before collecting the data from the sample, the researcher first asked the permission from the school principal using the permission letter of conducting researcher from faculty then face-timing both the English tecahers and having small discussions regarding the objectives of the research also asking for the access to joined the students whatsapp group, after getting the access the researcher then distributed the link of the Questionnaires to the students that researcher have choosen conveniently before from the students respond in whatsapp group. After sending the link, researcher then assisting the students to make sure that they answer the questionnaire properly and objectively without any preasure. This process lasts for about a month due to some problem that faced than written in the researcher field note. After the researcher got the data from the students, researcher face timing the English teachers conducting the interview and record it. After having the data that need, the researcher then inputing and analyzing the data in Microsoft excel 2019 then verified with SPSS app before formulating the discussion conclusion and suggestion.

\section{Questionnaire}

Questionnaire is an investigation by asking some questions in a written form. Zohrabi (2013) said that questionnaires are doubtless one of the primary sources of obtaining data in any research endeavor. Questionnaire is a widely used instrument for collecting survey information, providing structured, even numerical data.

The questionnaire used in this study was a questionnaire that made by the researcher that considered related to the objective of this research itself that was 
constructed to answer the problem statement of this research. The questionnaire has been validated by researcher supervisor as the representative of experts. The questionnaire consisted of 25 question items. With six variables that divided into: The general perception on-line learning, Perception of Students' achievement, Teacher Competence, Learning Media and Tools, Parental Support and Financial Support. The distribution of the questionnaires areas follow:

Variable of questionnaire

\begin{tabular}{|c|c|c|}
\hline No & Variables & $\begin{array}{c}\text { Number of } \\
\text { Questionnaire/Item }\end{array}$ \\
\hline 1 & $\begin{array}{c}\text { General Perception of on-line } \\
\text { learning }\end{array}$ & 4 \\
\hline 2 & $\begin{array}{c}\text { Perception on Students' } \\
\text { Achievement }\end{array}$ & 4 \\
\hline 3 & $\begin{array}{c}\text { Perception on Teacher } \\
\text { Competence }\end{array}$ & 4 \\
\hline 4 & $\begin{array}{c}\text { Perception on Learning Media and } \\
\text { Tools }\end{array}$ & 4 \\
\hline 5 & Perception on Parental Support & 4 \\
\hline 6 & Perception on Financial Support & 25 \\
\hline & Total Questionnaire & \\
\hline
\end{tabular}

The questions were in close-ended statement form. Closedended questions allow a limited number of answers, leaving no room for additional information to be volunteered; they require only recognition and a choice from among answer options. Closed-end questions are greater precision, uniformity, easier recall for the respondent, easier coding and easier analysis than open-ended questions. Siniscalco \& Auriat (2005) write that closed-ended questions ask the respondent to choose, among a possible set of answers, the response that most closely represents his/her viewpoint. The respondent is usually asked to tick or circle the chosen answer. Questions of this kind may offer simple alternatives such as 'Yes' or 'No'. They may also require that the respondent chooses among several answer categories, or that he/she uses a frequency scale, an importance scale, or an agreement scale.

Inside the questionnaire, the respondents were required to answer the questions about the things that represent their perspective on On-line learning process in English subject by choosing the answers that are provided by the researcher. All the statements of which were 25 statements in form of positively oriented using the scale of a Likert scale, where each answer ranged from 1 (strongly disagree), 2 (disagree), 3 (agree), and 4 (strongly agree).

\section{Interview}

Interview is the most important data collection technique in a qualitative researcher possesses. Fraenkel et al. (2012) point out that interview is an important way for a researcher to check the accuracy or to verify or refute impressions he or she has gained through previous data collection. The purpose of interviewing people is to find out what is on their minds, what they think or how they feel about something. The researcher used a semi structured interview in this study. Fraenkel et al. (2012) stated that semi structured interviews are verbal questionnaires. Rather formal, they consist of a series of questions designed to get specific answers from respondents. Often, they are used to obtain information that can later be compared and contrasted one another.

The researcher used semi structured interview in order to gain the additional data that are used to verify the data that are obtained from the students' questionnaire. The interview was conducted to two English teachers who teaches all the 14 classes that are involved in this study as the subject. The questions of the interview section for the teachers were also made by the researcher that have been validated by researcher's supervisor.

\section{Technique of Data Analysis}

In this data analysis, the data gained from the questionnaire was computed, and analyzed by using descriptive statistic. In order to calculate the results of the questionnaire, researcher used a mean score analysis and the collect data was coded according to the first research question of this study. The result of questionnaire also analyzed by using a rate scale by Likert (1932) and the percentage formula by Arikunto (2006):

Likert scale and its percentage

\begin{tabular}{|c|c|c|c|}
\hline $\begin{array}{c}\text { Rate Scale of the } \\
\text { Questionnaire }\end{array}$ & Scale Agreement & $\begin{array}{c}\text { Mean } \\
\text { Range }\end{array}$ & Note \\
\hline 4 & Strongly Agree & $\begin{array}{c}4.50- \\
5.00\end{array}$ & SA \\
\hline 3 & Agree & $\begin{array}{c}3.50- \\
4.49\end{array}$ & $\mathrm{~A}$ \\
\hline 2 & Dissagre & $\begin{array}{c}1.50- \\
2.49\end{array}$ & $\mathrm{D}$ \\
\hline 1 & Storongly & $\begin{array}{c}1.00- \\
1.49\end{array}$ & SD \\
\hline
\end{tabular}

After gaining the data researcher calculated the percentage of each questions/statements. According to Arikunto (2006) the formula of the percentage procedure is in this following:

The Percentage Formula Procedure

$$
\mathrm{P}=\mathrm{F}: \mathrm{N} \times 100 \%
$$

$\mathrm{P}=$ The percentage of the students' perception

$\mathrm{F}=$ The sum of the students' perception

$\mathrm{N}=$ The total of the students' perception

In this study the percentage was count by using Pivot in Microsoft Excel 2010

\section{Validity and Reliability}

Validity is a measure that shows the validity or the level of validity of an instrument. A valid instrument has high validity. Based on the correlation value, the criteria for whether or not the data is valid or not in the SPSS for Windows program is if r-count $>$ r-table, it means the item is valid. Otherwise, if $r$-count $<r$-table, it means the item is 
invalid. In the $5 \%$ significance, it is known that $\mathrm{r}$-table is 0.213 . The results of the validity test of 25 statement items have a value of r-count higher than 0.213 , so the questionnaire is declared valid and can be used in this study as the instrument.

The instrument reliability test for the questionnaire of perception on on-line English learning for the pre-sample was stated quite reliable because the value of alpha coefficients in the state of 0,54 . Hinton et al. (2004) have suggested four cutoff points for reliability, which includes excellent reliability ( 0.90 and above), high reliability (0.70-0.90), moderate reliability $(0.50-0.70)$ and low reliability $(0.50$ and below). While the result of the reliability test was 0.94 so that the level of reliability of the questionnaire which used by the researcher was conveniently reliable.

\section{FINDINGS AND DISCUSSION}

\section{Findings}

The data about the students' perceptions on on-line learning in English subject. Based on result of data analysis by using Likert Scale with the following value: ( $\mathrm{SD}=$ strongly disagree, $\mathrm{D}=$ disagree, $\mathrm{A}=$ agree, and $\mathrm{SA}=$ strongly agree). The researcher then arranges the students' perception from the general conditions until the financial support and the percentage of each variable are in the following table and description:

1. General Perception of On-line Learning

\begin{tabular}{|c|c|c|c|c|c|c|}
\hline \multirow{2}{*}{$\begin{array}{l}\mathrm{N} \\
\mathrm{o}\end{array}$} & Statements & \multicolumn{3}{|c|}{ Scale \& Percentage } & \multirow{2}{*}{ Total } \\
\cline { 3 - 6 } & $\mathrm{SD}$ & $\mathrm{D}$ & $\mathrm{A}$ & $\mathrm{SA}$ & \\
\hline 1 & $\begin{array}{c}\text { During the pandemic, English on- } \\
\text { line learning is very much needed }\end{array}$ & $\begin{array}{c}1 \\
\%\end{array}$ & $\begin{array}{c}6 \\
\%\end{array}$ & $\begin{array}{c}59 \\
\%\end{array}$ & $\begin{array}{c}34 \\
\%\end{array}$ & \multirow{2}{*}{$100 \%$} \\
\hline 2 & $\begin{array}{c}\text { English On-line learning is better } \\
\text { than face-to-face learning }\end{array}$ & $\begin{array}{c}45 \\
\%\end{array}$ & $\begin{array}{c}51 \\
\%\end{array}$ & $\begin{array}{c}3 \\
\%\end{array}$ & - & $100 \%$ \\
\hline \multirow{2}{*}{3} & $\begin{array}{c}\text { In the English on-line learning } \\
\text { process students and teachers are } \\
\text { more interactive in discussing }\end{array}$ & $\begin{array}{c}26 \\
\%\end{array}$ & $\begin{array}{c}59 \\
\%\end{array}$ & $\begin{array}{c}14 \\
\%\end{array}$ & $1 \%$ & $100 \%$ \\
\hline \multirow{2}{*}{4} & $\begin{array}{c}\text { Students are always passionate and } \\
\text { attentive in English on-line } \\
\text { learning }\end{array}$ & $\begin{array}{c}24 \\
\%\end{array}$ & $\begin{array}{c}55 \\
\%\end{array}$ & $\begin{array}{c}17 \\
\%\end{array}$ & $3 \%$ & $100 \%$ \\
\hline
\end{tabular}

The result of the statement, first, students' awareness is good when it comes to the importance in maintaining a distance which makes it impossible to do face-to-face learning as usual where only $7 \%$ of the 86 respondents who expressed their disagreement. Second, almost all students disagree that online learning is better compared to face-to-face, it can be seen that $97 \%$ equal to 83 from 86 respondents who disagree that on-line learning is better than face-to-face. Third, only about $15 \%$ from 86 students agree with the statement that in on-line learning students and teachers are more interactive, while the other $85 \%$ are disagree. Fourth, $80 \%$ of respondents claiming to be less enthusiastic and less attentive to learning on-line, while only about $20 \%$ who fell the opposite.
2. Perception on Students' achievement

\begin{tabular}{|c|c|c|c|c|c|c|}
\hline \multirow{2}{*}{$\begin{array}{c}\mathrm{N} \\
\mathrm{o}\end{array}$} & Statements & \multicolumn{3}{|c|}{ Scale \& Percentage } & \multirow{2}{*}{ Total } \\
\cline { 3 - 6 } & & $\mathrm{S}$ & $\mathrm{D}$ & $\mathrm{A}$ & $\mathrm{SA}$ & \\
\hline \multirow{2}{*}{1} & $\begin{array}{c}\text { On-line learning can increase } \\
\text { students score in English subject }\end{array}$ & $\begin{array}{c}19 \\
\%\end{array}$ & $\begin{array}{c}52 \\
\%\end{array}$ & $\begin{array}{c}28 \\
\%\end{array}$ & $\begin{array}{c}1 \\
\%\end{array}$ & $\begin{array}{c}100 \\
\%\end{array}$ \\
\hline 2 & $\begin{array}{c}\text { English On-line learning is too } \\
\text { much of a task so it is burdensome }\end{array}$ & $\begin{array}{c}7 \\
\%\end{array}$ & - & $\begin{array}{c}49 \\
\%\end{array}$ & $\begin{array}{c}44 \\
\%\end{array}$ & $\begin{array}{c}100 \\
\%\end{array}$ \\
\hline \multirow{2}{*}{3} & $\begin{array}{c}\text { On-line learning makes it difficult } \\
\text { to meet classmates to motivate } \\
\text { each other to learn English }\end{array}$ & 1 & 8 & 40 & 51 & 100 \\
& $\%$ & $\%$ & $\%$ & $\%$ \\
\hline 4 & $\begin{array}{c}\text { My English on-line exam process } \\
\text { is not as complicated as face to } \\
\text { face }\end{array}$ & $\begin{array}{c}\% \\
\%\end{array}$ & $\begin{array}{c}37 \\
\%\end{array}$ & $\begin{array}{c}40 \\
\%\end{array}$ & $\begin{array}{c}14 \\
\%\end{array}$ & $\begin{array}{c}100 \\
\%\end{array}$ \\
\hline
\end{tabular}

First, only 25 students or $29 \%$ of all respondents felt their grades had increased in on-line learning, the remaining $71 \%$ stated that grades did not increase through on-line learning. Second, $93 \%$ of respondents or the same as 80 students out of the 86 students who became respondents, stated that on-line learning was too burdensome for them in terms of assignments given by the teacher. Third, $91 \%$ from 86 students agree that on-line learning makes meeting difficult classmates to motivate each other to learn. Fourth, from 86 respondents about $46 \%$ who do not / disagree with the statement but there are $54 \%$ of respondents who agree / strongly agree. This can indicate that the media used in the exam is already effective and can be used by students.

3. Perception on Teacher Competence

\begin{tabular}{|c|c|c|c|c|c|c|}
\hline \multirow{2}{*}{$\begin{array}{c}\mathrm{N} \\
\mathrm{O}\end{array}$} & Statements & \multicolumn{3}{|c|}{ Scale \& Percentage } & \multirow{2}{*}{ Total } \\
\cline { 3 - 6 } & $\begin{array}{c}\mathrm{S} \\
\mathrm{D}\end{array}$ & $\mathrm{D}$ & $\mathrm{A}$ & $\begin{array}{c}\mathrm{S} \\
\mathrm{A}\end{array}$ & \\
\hline \multirow{2}{*}{1} & $\begin{array}{c}\text { Learning media by English } \\
\text { teachers through on-line is very } \\
\text { helpful for understanding learning }\end{array}$ & $\begin{array}{c}9 \\
\%\end{array}$ & $\begin{array}{c}55 \\
\%\end{array}$ & $\begin{array}{c}35 \\
\%\end{array}$ & $\begin{array}{c}1 \\
\%\end{array}$ & $\begin{array}{c}100 \\
\%\end{array}$ \\
\hline \multirow{2}{*}{2} & $\begin{array}{c}\text { Learning materials provided by } \\
\text { the teacher on-line are very } \\
\text { helpful for understanding learning }\end{array}$ & $\begin{array}{c}8 \\
\%\end{array}$ & $\begin{array}{c}64 \\
\%\end{array}$ & $\begin{array}{c}27 \\
\%\end{array}$ & $\begin{array}{c}1 \\
\%\end{array}$ & $\begin{array}{c}100 \\
\%\end{array}$ \\
\hline & $\begin{array}{c}\text { The assignments given by the } \\
\text { teacher in on-line learning are } \\
\text { very helpful in understanding } \\
\text { learning }\end{array}$ & $\begin{array}{c}15 \\
\%\end{array}$ & $\begin{array}{c}59 \\
\%\end{array}$ & $\begin{array}{c}26 \\
\%\end{array}$ & - & $\begin{array}{c}100 \\
\%\end{array}$ \\
\hline 4 & $\begin{array}{c}\text { Teachers' performance in teaching } \\
\text { English in face-to-face is better } \\
\text { than on-line }\end{array}$ & $\begin{array}{c}8 \\
\%\end{array}$ & $\begin{array}{c}24 \\
\%\end{array}$ & $\begin{array}{c}26 \\
\%\end{array}$ & $\begin{array}{c}42 \\
\%\end{array}$ & $\begin{array}{c}100 \\
\%\end{array}$ \\
\hline 5 & $\begin{array}{c}\text { On-line learning must also be } \\
\text { accompanied by offline learning } \\
\text { with teacher visits to students' } \\
\text { homes }\end{array}$ & 12 & 42 & 42 & 5 & 100 \\
$\%$ & & $\%$ & $\%$ & $\%$ \\
\hline
\end{tabular}

First statement is from 86 respondents only $36 \%$ of respondents agree that the learning media by teachers through on-line is very helpful for understanding learning. Second, from 86 respondents there are $72 \%$ of respondents stated that they disagree about the Learning Material what the teacher provides on-line is very helpful for understanding learning. Third, from 86 respondents which there are $74 \%$ of respondents do not agree with the statement the assignments given by the teacher in learning on-line is very helpful in understanding learning. Fourth, from 86 respondents there are 28 students or $32 \%$ who agree that the performance of teachers in on-line learning is better than face-to-face while 
the remaining 48 or $68 \%$ disagree that teacher performance in on-line learning is better than face-to-face. Fifth, there are $47 \%$ from 86 respondents who agree that teachers must also visit students 'homes for learning effectiveness, but what is interesting is $53 \%$ of respondents who disagree that students should be visited by teachers.

4. Perception on Learning Media and Tools

\begin{tabular}{|c|c|c|c|c|c|c|}
\hline \multirow[b]{2}{*}{ No } & \multirow[b]{2}{*}{ Statements } & \multicolumn{4}{|c|}{ Scale \& Percentage } & \multirow[b]{2}{*}{ Total } \\
\hline & & $\begin{array}{l}\mathrm{S} \\
\mathrm{D}\end{array}$ & $\mathrm{D}$ & A & $\begin{array}{l}\mathrm{S} \\
\mathrm{A}\end{array}$ & \\
\hline 1 & $\begin{array}{l}\text { On-line learning in English is } \\
\text { irrelevant to my current state of } \\
\text { electronic devices }\end{array}$ & $\begin{array}{l}15 \\
\%\end{array}$ & $\begin{array}{l}34 \\
\%\end{array}$ & $\begin{array}{l}45 \\
\%\end{array}$ & $\begin{array}{c}6 \\
\%\end{array}$ & $\begin{array}{c}100 \\
\%\end{array}$ \\
\hline 2 & $\begin{array}{l}\text { English On-line learning has } \\
\text { many problems with signal } \\
\text { interference during teaching and } \\
\text { learning activities }\end{array}$ & - & $\begin{array}{c}7 \\
\%\end{array}$ & $\begin{array}{l}45 \\
\%\end{array}$ & $\begin{array}{l}48 \\
\%\end{array}$ & $\begin{array}{c}100 \\
\%\end{array}$ \\
\hline 3 & $\begin{array}{c}\text { The interface / media display that } \\
\text { teachers use in English on-line } \\
\text { learning is very troublesome for } \\
\text { me }\end{array}$ & $\begin{array}{l}13 \\
\%\end{array}$ & $\begin{array}{l}52 \\
\%\end{array}$ & $\begin{array}{l}28 \\
\%\end{array}$ & $\begin{array}{c}7 \\
\%\end{array}$ & $\begin{array}{c}100 \\
\%\end{array}$ \\
\hline 4 & $\begin{array}{l}\text { Schools fully assist me in English } \\
\text { on-line learning in terms of } \\
\text { internet data and etc }\end{array}$ & $\begin{array}{l}3 \\
\%\end{array}$ & $\begin{array}{l}20 \\
\%\end{array}$ & $\begin{array}{l}62 \\
\%\end{array}$ & $\begin{array}{l}15 \\
\%\end{array}$ & $\begin{array}{c}100 \\
\%\end{array}$ \\
\hline
\end{tabular}

First statement, from 86 respondents there are $51 \%$ of students who feel that the devices they have are not able to support online learning and the remaining $49 \%$ already have supportive tools. Second, from 86 students as the respondents there are $93 \%$ of respondents agree that on-line learning encountered many problems with signal interference during teaching and learning activities. Third, there are $65 \%$ of respondents who stated that they disagree that the application interface used by the teacher in learning was difficult for them while the other $35 \%$ agree about the statement. Fourth, from the 86 respondents there are $77 \%$ of students have experienced it, but there is a small portion of $23 \%$ who have not felt the provided assistance regarding learning media to support their on-line learning activity.

5. Perception on Parental Support

\begin{tabular}{|c|c|c|c|c|c|c|}
\hline \multirow{2}{*}{ No } & Statements & \multicolumn{3}{|c|}{ Scale \& Percentage } & \multirow{2}{*}{ Total } \\
\cline { 3 - 5 } & $\begin{array}{c}\text { S } \\
\text { D }\end{array}$ & D & A & $\begin{array}{c}\text { S } \\
\text { A }\end{array}$ & \\
\hline \multirow{2}{*}{2} & $\begin{array}{c}\text { English On-line learning disrupts } \\
\text { time helping parents at home } \\
\text { during a pandemic }\end{array}$ & $\begin{array}{c}8 \\
\%\end{array}$ & $\begin{array}{c}42 \\
\%\end{array}$ & $\begin{array}{c}37 \\
\%\end{array}$ & $\begin{array}{c}13 \\
\%\end{array}$ & $\begin{array}{c}100 \\
\%\end{array}$ \\
\hline \multirow{2}{*}{3} & $\begin{array}{c}\text { Parents do not understand much } \\
\text { of the English on-line learning } \\
\text { process so they don't accidentally } \\
\text { interfere with learning time }\end{array}$ & $\begin{array}{c}9 \\
\%\end{array}$ & $\begin{array}{c}22 \\
\%\end{array}$ & $\begin{array}{c}44 \\
\%\end{array}$ & $\begin{array}{c}24 \\
\%\end{array}$ & $\begin{array}{c}100 \\
\%\end{array}$ \\
\hline 4 & $\begin{array}{c}\text { Because English on-line learning } \\
\text { students have more time with } \\
\text { family }\end{array}$ & 2 & 17 & 55 & 26 & 100 \\
$\%$ & $\begin{array}{c}\text { Beside on-line learning also } \\
\text { conducted English learning with } \\
\text { parents so that help students to } \\
\text { understand the learning }\end{array}$ & $\begin{array}{c}13 \\
\%\end{array}$ & $\begin{array}{c}48 \\
\%\end{array}$ & $\begin{array}{c}34 \\
\%\end{array}$ & $\begin{array}{c}6 \\
\%\end{array}$ & $\begin{array}{c}100 \\
\%\end{array}$ \\
\hline
\end{tabular}

From the first statement, there were $50 \%$ of respondents from the total 86 who agree that on-line learning interferes with the time to help parents at home during a pandemic. While the other half were not. Second, there are $68 \%$ from the total 86 respondents agree with the statement that ineffective on-line teaching and learning activities are also caused by the factor of parents who do not understand on-line school activity so that it is possible to interfere with the learning process. Third, from 86 respondents there are $81 \%$ who agree that because on-line learning is more time together with family. Fourth, from 86 respondents, there are $61 \%$ who stated that in addition to learning on-line, learning with parent/guardian is also very helpful to understand the learning.

6. Perception on Financial Support

\begin{tabular}{|c|c|c|c|c|c|c|}
\hline \multirow[b]{2}{*}{ No } & \multirow[b]{2}{*}{ Statements } & \multicolumn{4}{|c|}{ Scale \& Percentage } & \multirow[b]{2}{*}{ Total } \\
\hline & & $\begin{array}{l}\mathrm{S} \\
\mathrm{D}\end{array}$ & $\mathrm{D}$ & A & SA & \\
\hline 1 & $\begin{array}{c}\text { English On-line learning } \\
\text { eliminates the opportunity to save } \\
\text { money from having to buy internet } \\
\text { data } \\
\end{array}$ & $\begin{array}{c}5 \\
\%\end{array}$ & $\begin{array}{l}16 \\
\%\end{array}$ & $\begin{array}{l}48 \\
\%\end{array}$ & $\begin{array}{l}31 \\
\%\end{array}$ & $\begin{array}{c}100 \\
\%\end{array}$ \\
\hline 2 & $\begin{array}{l}\text { On-line learning is more } \\
\text { economical because there is no } \\
\text { need to buy printed books because } \\
\text { they are all in e-book form }\end{array}$ & $\begin{array}{l}12 \\
\%\end{array}$ & $\begin{array}{l}44 \\
\%\end{array}$ & $\begin{array}{l}33 \\
\%\end{array}$ & $\begin{array}{l}12 \\
\%\end{array}$ & $\begin{array}{c}100 \\
\%\end{array}$ \\
\hline 3 & $\begin{array}{l}\text { English On-line learning helps the } \\
\text { economy of parents to save money } \\
\text { because they don't need to spend } \\
\text { pocket money in school }\end{array}$ & $\begin{array}{c}8 \\
\%\end{array}$ & $\begin{array}{l}35 \\
\%\end{array}$ & $\begin{array}{l}48 \\
\%\end{array}$ & $\begin{array}{c}9 \\
\%\end{array}$ & $\begin{array}{c}100 \\
\%\end{array}$ \\
\hline 4 & $\begin{array}{l}\text { English On-line learning is very } \\
\text { burdensome for parents in } \\
\text { purchasing data packages }\end{array}$ & $\begin{array}{l}13 \\
\%\end{array}$ & $\begin{array}{l}27 \\
\%\end{array}$ & $\begin{array}{l}47 \\
\%\end{array}$ & $\begin{array}{l}14 \\
\%\end{array}$ & $\begin{array}{c}100 \\
\%\end{array}$ \\
\hline
\end{tabular}

From the first statement, where $79 \%$ from 86 students agree that they missed the opportunity to save because they had to buy internet data. Second, there were 56\% from 86 respondents disagree with the statement that due to on-line learning students will save more money due to the availability of e-book. Third, there are $43 \%$ from 86 respondents disagree with the statement that on-line learning helps the economy of parents to save money because they do not need to spend pocket money at school while the other dominant respondent agree. Fourth, from 86 respondents who gave answers, only about $40 \%$ who disagree that the internet data was a burden on parents and the remaining $60 \%$ agree that the internet data was a burden to their parents

\section{DISCUSSION}

Based on the findings of the study, the data obtained is quite convincing for the researcher that on-line learning nowadays is ineffective where most of the respondents have bad perspective on how the on-line learning related to them. According to the findings of the questionnaire and interview, they were six variables where they are On-line English learning in general perception, Students' achievement, Teacher Competence, Learning Media, Parental Support and Financial Support which are elaborated in the discussion below:

\section{General perception of on-line learning}

The increases of casualties caused by Covid-19 makes the awareness of students is improved either but it's not certainly made their on-line English learning better because students 
still prefer conventional (face-to-face) learning rather than online. As stated by Castle \& McGuire (2010) "Students appreciated online learning for its potential in providing a clear and coherent structure of the learning material, in supporting self-regulated learning, and in distributing information. They preferred face-to-face learning for communication purposes in which a shared understanding has to be derived or in which interpersonal relations are to be established". Despite that, the limit of interaction caused the students less enthusiasm in English on-line learning.

\section{Perception on Students' achievement}

English on-line learning is ineffective in terms of improving students score. An especially important result concerns students' perceptions of their learning achievements: When conceptual knowledge in the subject matter or skills in the application of one's knowledge are to be acquired; students prefer face-to-face learning (Castle \& McGuire, 2010). The tendency of less enthusiastic on joining English on-line learning made the students feel burdensome when gating project or homework from the English teacher. Also, the need for interacting and socializing among students that limited by the on-line learning also play a big role on decreasing students' enthusiasm.

\section{Perception on Teachers' Competence}

English teacher competence in adopting their way of teaching into on-line was really essential for making the English on-line learning environment helpful for the students. Digital teacher competence and teacher education opportunities to learn digital competence are instrumental in adapting to online teaching during COVID-19 school closures (Alvarez et al., 2009). Most online courses today lack creativity and/or interactivity when it comes to deliver instructional materials. Cognitivists believe that the addition of multimedia can help improve and augment the learning process of students as they see the concept in action (Michelich, 2002). According to students' perception in this study, the material and media used by the English teacher were not helping the students in a better way for gain a better understanding. It's proven by students' perception that teacher performance in conventional (face-to-face) learning method is way better than the present on-learning. The teacher worse performance also admitted on interview result where the English teachers stated that do not have any knowledge from any specific training from the government for conducting the on-line English learning that made them only using their individual intuition in developing their competence in on-line learning environment.

\section{Perception on Learning Media and Tool}

Tools and media which used during on-line learning were the bridge for the students and the teacher in conducting English on-line learning. The most crucial part of it was students' devices most students still do not have a supportive tool. The economical factor of each student was the main factor. It could be different economic factors from each student. The inconsistency of the internet network that depends on may factors, such as, palaces, prices and the provider caused an obstacle for the students to make their online learning better. Educators are always looking for effective ways to create productive learning environments. The use of google meet, google classroom, WhatsApp and other familiar platforms from the teachers has helped the students easily understanding the user interface of the media that used.

\section{Perception on Parental Support}

On-line learning which conducted at home required the role of parents to successively help the students at home although for same cases, according to Dong et al. (2020), the parents generally had negative beliefs about the values and benefits of online learning and preferred traditional learning in early childhood settings. They tended to resist and even reject online learning for three key reasons: the shortcomings of online learning, young children's inadequate self-regulation, and their lack of time and professional knowledge in supporting children's online learning. Also, the hardship caused by the COVID-19 pandemic has made them suffering, thus more resistant to online learning at home. The understanding of parents is really needed by students for their learning from home to utilize the time and togetherness both parents and students, despite as a psychological support for the students also as a replacement for their classmate.

\section{Perception on Financial Support}

Performing an effective on-line learning is still far from successful. The cost that spent and used for on-line learning activity especially from students' perception is quite high, despite they spent for internet data, fulfilling the requirement of a sufficient tool and media. And for high school students cost it mostly still handled by parents. On the other hand, due to on-line students and parents do not have to spent for daily activated that conventionally spent for activity at school. The uncertainty also stated by Deming et al. (2015) "Although the pattern of results suggests some hope that online technology can "bend the cost curve" in higher education, the impact of online learning on education quality remains uncertain".

\section{CONCLUSIONS}

Students' awareness of the dangerous of COVID-19 pandemic is not followed by their believe that on-line learning is better than conventional face-to-face, the limit of interaction and feedback makes the students less enthusiast. It causes students score/grade has no significant improvement. The burdensome of homework and project from the English teacher contributes in making students less enthusiast. At the same time, the burdensome did not accompanied by the support and motivation of the students' friends that they usually got in face-to-face learning The English teacher bad performance in line with the learning media and material used. Insufficient network and some supportive digital components cause trouble for most student in their English 
learning. Although students have more family time from home, the lack of understanding regarding the on-line learning cause an interfere from parents during the process and parents did not really help the students during the on-line learning. The inability of make saving also faced by the students due to the fact that students have to use their money for supporting the needs of their English on-line learning.

\section{REFERENCES}

[1] Alvarez, I., Guasch, T., \& Espasa, A. (2009). University teacher roles and competencies in online learning environments: A theoretical analysis of teaching and learning practices. European Journal of Teacher Education, 32(3), 321-336. https://doi.org/10.1080/02619760802624104

[2] Arikunto, S. (2006). Prosedur penelitian: Suatu pendekatan praktik. Rineka Cipta.

[3] Castle, S. R., \& McGuire, C. (2010). An Analysis of Student SelfAssessment of Online, Blended, and Face-to-Face Learning Environments: Implications for Sustainable Education Delivery. International Education Studies, 3(3), p36. https://doi.org/10.5539/ies.v3n3p36

[4] Creswell, J. W. (2012). Educational research: Planning, conducting, and evaluating quantitative and qualitative research. Pearson Education.

[5] Deming, D. J., Goldin, C., Katz, L. F., \& Yuchtman, N. (2015) Can Online Learning Bend the Higher Education Cost Curve?
American Economic Review, 105(5), 496-501. https://doi.org/10.1257/aer.p20151024

[6] Dong, C., Cao, S., \& Li, H. (2020). Young children's online learning during COVID-19 pandemic: Chinese parents' beliefs and attitudes. Children and Youth Services Review, 118, 105440. https://doi.org/10.1016/j.childyouth.2020.105440

[7] Fraenkel, J. R., Wallen, N. E., \& Hyun, H. H. (2012). How to desIgn and evaluate research In educatIon (8th ed.). Mc Graw Hill.

[8] Groves, R. M. (2010). Survey Methodology (Second edition of the (2004) first edition).

[9] Hinton, P., McMurray, I., \& Brownlow, C. (2004). SPSS $\begin{array}{llll}\text { Explained } & (0 & \text { ed.). }\end{array}$ https://doi.org/10.4324/9780203642597

[10] Imansyah, M. (2019). Factor Affecting Students Speaking Confidence at the Eleventh Garde Tourism Students at SMK Negeri 1 Palu. Universitas Tadulako.

[11] Likert, R. (1932). A technique for measurement of attitudes (Vol. 22). The Science Press.

[12] Michelich, V. (2002). Streaming media to enhance teaching and improve learning. The Technology Source.

[13] Siniscalco, M. T., \& Auriat, N. (2005). Questionnaire design: Quantitative research methods in educational planning. UNESCO International Institute for Educational Planning.

[14] Zohrabi, M. (2013). Mixed Method Research: Instruments, Validity, Reliability and Reporting Findings. Theory and Practice in Language Studies, 3(2), 254-262. https://doi.org/10.4304/tpls.3.2.254-262 